\title{
MRGPRX2 Gene
}

National Cancer Institute

\section{Source}

National Cancer Institute. MRGPRX2 Gene. NCI Thesaurus. Code C124958.

This gene plays a role in both $\mathrm{G}$ protein-coupled receptor signaling and mast cell activation. 